\title{
THE ROLE OF PROFESSIONAL COMMITMENT AND SUSPENSION OF JUDGMENT IN DECREASING AUDITORS' PREMATURE SIGN-OFF
}

\author{
Andi Ina Yustina ${ }^{1)}$, Irina Kristela Sutarsa ${ }^{2)}$ \\ President University ${ }^{1,2)}$
}

\begin{abstract}
Premature sign-off is the action that can affect to reduced audit quality. The objectives of this research are to examine the effect of professional commitment and suspension of judgment towards premature sign-off. The researcher used the survey method on auditor working in a big ten public accounting firm in Jakarta. There is a total of 126 respondents who contributed to this research. The data was analyzed using Structural Equation Model-Partial Least Squares (SEM-PLS) analysis. The data quality test results of the reliability and validity test show that all variables can be said to be valid and reliable. This research shows that professional commitment is positively significant to suspension of judgment but negatively affects premature sign-off. The suspension of the judgment of the auditors fully mediates the relation between professional commitment and premature sign-off.
\end{abstract}

Keywords: Premature Sign-Off, Professional Commitment, Suspension of Judgment.

Corresponding author: a.inayustina@gmail.com

Email : a.inayustina@gmail.com, irina.kristela@gmail.com

DOI : https://doi.org/10.33369/j.akuntansi.9.3.153-164

\section{INTRODUCTION}

The auditor performs the audit procedures following professional auditing standards to give assurance of the audited financial statements. The auditor must act independent and dependable as the auditee is a non-expert and not able to ascertain. Despite that, several auditors failed to comply with the auditing standard, and this action was defined as dysfunctional audit behaviour (Obeid et al. 2017; Ling and Akers, 2010).

According to Shapeero et al. (2003), dysfunctional audit behaviour, especially premature sign-off has a direct relation to audit quality. At the practice, poor execution of audit procedures reduces the level of evidence gathered in the audit. As a result, the evidence is unreliable, false, or inadequate quantitatively or qualitatively. It could be described as audit quality reduction behavior. Prior researches from Svanberg and Ohman, (2019), Lee (2002), and Otley and Pierce (1996) have been examined several behaviors included in the audit quality reduction behavior. The responses are a reduction of work below what would generally be considered reasonable, a cursory review of client documents, acceptance of weak client explanations; failure to research an accounting principle; failure to pursue a questionable item; false or premature sign-off. All behaviors have one aspect that influenced the audit quality, which is the proper execution of audit work programs. The auditors who are reducing the care and skepticism in the auditing process could endanger the engagement and validity of the audit opinion.

The study from Svanberg and Ohman, (2019) stated that premature sign-off is one of the behaviors that have a direct impact on audit quality. Meanwhile, according to Kelley and Margheim (1990), underreporting of time is the behavior that has an indirect relation to audit quality, which resulted in poor decisions and increased the need for budget revisions and time pressure for the future audit. Past studies have found that many accountants have performed 
this dysfunctional audit behavior. First, Rhode (1977) researched a premature signing-off of a required audit procedure, resulting in $60 \%$ of the respondents having done it sometime during their careers. Following the research, Alderman and Deitrick (1982) found that premature sign-off occurred in not only local and regional firms but also the national firms. A study conducted by Otley and Pierce (1995) also found that $89 \%$ of participants have done premature sign-off, and the rest led underreporting of time.

Moreover, the social image of auditing is highly associated with the preservation of a high level of "professionalism" applied to the job. In that case, the apparent auditor behavior is as important as work methods or technical competence, since behavioral aspects are more visible (Gray, 1998). High levels of technical knowledge and training are characteristic of the accounting profession that might influence the relative importance of each dimension of professional commitment in explaining the audit outcomes (Hall et al. 2005).

Research from Yustina and Gonadi (2019), Chiang (2016), and Hurtt et al. (2013) state that audit quality is also influenced by professional skepticism. This cautious behavior is very mandatory for every auditor because it involves the output of the report it produces. Because of this importance, audit standards make a professional skepticism as one of the mandatory behaviors for auditors (SAS, 1997). To support SAS in setting the standard of behavior of an auditor, Hurtt (2010) described in his research dividing professional skepticism into six parts, one of which is a suspension of judgment. SAS insists that an auditor must gather complete evidence before making judgments (SAS, 1997a).

A prior studies on logical relations between auditors' professional commitment and experience on ethical evaluations and decision making, including premature sign-off shows mix result. For example, Otley and Pierce (1996) find no significant relationship between auditors' professional commitment and premature sign-off. Kaplan and Whitecotton (2001) found that there is a positive relationship between sufficient professional commitment and auditor's responsibility for reporting. In consideration of the mixed result of prior studies, this study aims to examine the impact of those characteristics towards auditor intention to do premature sign-off. Herda and Martin (2016) conducted a study that examined the effect of professional commitment towards auditor's purpose in underreporting. Their study observed that there is a significant relationship between professional commitment and underreporting acceptance, influenced by auditor experience level. In addition, prior studies had examined judgment auditor to professional skepticism (Yustina and Gonadi (2019); Hurtt (2010); Nelson (2009); Otley and Pierce (1995). There is no study before explaining the relationship between professional commitment, professional skepticism (including suspension of judgment), and premature sign-off. Therefore, the researcher proposed to expand the following study by examining the impact of professional commitment toward another dysfunctional behavior, which is auditor's intention in premature sign-off. According to Nelson (2009), auditor's pre-existing knowledge, traits, incentives, and suspension of judgment could influence audit judgment and audit actions. In line with that, Nelson (2009) argues that suspension of judgment can impact the quality of audit outcomes, which is premature sign-off.

\section{THEORETICAL FRAMEWORK AND HYPOTHESIS}

\section{Professional Commitment}

Professional Commitment becomes a factor that could influence an auditor in accepting the dysfunctional audit behavior, which in this study refers to the premature sign-off. According to Aranya and Ferris (1984), professional commitment could be described as the level of individual identification, which involves in a profession includes the reliance and acceptance of the objectives, principles of the willingness to employ effort, and a desire to be 
a part of the job. Furthermore, the concept of professional commitment is generally categorized into the three-dimensional construct that consists of affective, continuance, and normative professional commitment. Examining each concept could help find the correlation between professional commitment and audit behavior.

First, affective commitment is related to the attachment that individuals had to stay within the focal entity, which can result in both positive and negative outcomes for the body (Meyer and Allen 1997). Essentially, the concept of affective commitment is when an individual had a willingness to stay within the entity. Second, continuance commitment is the concept of the extent to which individuals tended to "have to stay" within the focal object. Based on Becker's (1960) theory, the reasons individuals remain committed to the entity are due to an accumulation of investments associated with the focal body or a lack of alternatives. Third, when individuals believe that they "ought to stay" to the focal entity, it could be categorized as normative commitment (Mayer and Allen, 1997). The last stages of commitment could arise from the socialization experiences that emphasize the relevance of becoming part of the entity or when the individuals receive the benefits and perceive to reciprocate towards them (Mayer and Allen, 1997).

Hall et al. (2005) explained that professional commitment has a relation to auditor signoff judgments, which also influence by several antecedents and correlates. The explanation also supported by a study from Lord and Dezoort (2001), which resulted that auditors with a lower level of affective commitment tend to signed-off higher account balances compared to auditors with a high level of affective commitment. Also, according to Kaplan and Whitecotton (2001) which found that there is a positive relation between affective commitment and auditor's responsibility for reporting, which was, in turn, positively related to auditor's reporting intention.

\section{Suspension of Judgement}

Hurtt (2010) developed a professional skepticism scale, which also defined professional skepticism into six multi-dimensional constructs that consist of characteristics: a questioning mind, a suspension of judgment, a search for knowledge, interpersonal understanding, self-esteem, and autonomy. in this study, the researcher focuses on one specific characteristic of professional skepticism, which is a suspension of judgment. Based on Hurtt's (2010) research, suspension of judgment is one of the skeptic characteristics that can trigger a person to form an understanding and eager to develop other skeptic characteristics. Philosophers view skeptics as unwilling traits to admit assertions and claims, and instead, as keeping an open mind and critically evaluating (Hallie, 1985; Kurtz, 1992), also stated that suspension of judgement becomes an essential element of skeptical inquiry. In psychology view, suspension of judgment is that characteristic that closely related to the need for cognitive closure.

The need of cognitive closure itself could be described as "the desire for a definite answer on some topic, any answer as opposed to confusion and ambiguity" (Kruglanski, 1989), and this desire shortly defined as a desire for a clear-cut answer on a topic that requires judgmental decision-making. Under the auditing standards, SAS No. 1 indicates the importance of suspending judgment until sufficient evidence is collected, and persuasive evidence is found (Hallie, 1985; Kurtz, 1992).

\section{Premature Sign-off}

The auditor should do the audit procedures based on the professional auditing standards. Meanwhile, several auditors failed to comply with the rules and this action known as 
dysfunctional audit behavior (Otley and Pierce, 1996). According to Paino et al. (2010), premature sign-off is the following behavior includes failure to research an accounting principle, premature sign-off of audit procedures, a quick review of documents, acceptance of weak client explanations, and reduction of work on an audit step below the acceptable level. Additionally, Shapeero et al. (2003) defined premature sign-off as an act when the auditor documents the completion of a required procedure that is not supported by other audit procedures, without performing the work or noting the procedures' emission. Unlike the underreporting, which occurred when the audit procedures were already implemented, premature sign-off has a direct effect on the audit quality and also violates the professional auditing standard.

\section{Hypothesis Development}

\section{Professional Commitment and Suspension of Judgement}

A prior study by Meyer et al. (1993) argues that each dimension of professional commitment could affect an individual's work performance. Furthermore, the study stated that individuals with a high level of affective professional commitment and normative professional commitment are likely to be more updated with developments of the profession and more involved in the activities required to keep within the organization. Moreover, individuals with a high level of professional commitment should have a greater sensitivity towards professional ethics (Lord \& DeZoort, 2001), which resulted in more responsibility to comply with the existing professional standards. On the other hand, suspension of judgment is the essential element of individuals' being skeptic in making a judgment until sufficient evidence is gathered. This character helps auditors to comply with the professional auditing standards regarding audit evidence.

Although there is no recent study that relates the concept between professional commitment and suspension of judgment, the researcher found the same goal between those variables. Both professional commitment and suspension of judgment are likely to enhance auditor's compliance in collecting the evidence. Based on the following concept, the researcher constructs the next idea:

$\mathrm{H}_{1}$ : Professional commitment has a positive relation toward the suspension of judgment.

\section{Suspension of Judgement and Premature sign-off}

Prior study in psychology found that dispositional characteristics or traits (included a tendency to exhibit suspicious behavior) could influence judgment and decisions (Ajzen, 2005). Moreover, based on the study of professional skepticism in auditing, Nelson (2009), implies that auditors with a more skeptical disposition will exhibit more skeptical judgments and decisions than auditors with a less cynical nature. The auditors would suspend their experience and do a more substantive test to result in a more evidential outcome.

Those characteristics improved the auditor's willingness to search and fully observe the evidence before making the judgment. As stated from the following theory, auditors that done premature sign-off will not complete their job while not all audit procedures are done correctly. Therefore, a high level of suspension of judgment will likely make the auditors hold their decision until all trusted evidence collected. Such an eager intention of the auditor to gather the proof could minimize the potency of premature sign-off. Accordingly, the researcher constructs the idea:

$\mathrm{H}_{2}$ : Suspension of judgment has a negative relation to premature sign-off. 


\section{Suspension of judgment, professional commitment, and premature sign-off}

Aranya and Ferris (1984) found that a certified public accountant or external auditor has a higher level of professional commitment than the one who works in an industrial or governmental organization. Moreover, they stated that the interaction of professional commitment could help predict professional conflict. The result of their study explained that auditors with a high level of professional commitment experience less professional conflict and vice versa. Meanwhile, premature sign-off is the conflict that occurred due to the individual fails to comply with the professional audit standard (Shapeero et al. (2003).

According to Hurtt (2010), the first characteristic of professional skepticism, which includes a questioning mind, suspension of judgment, and searches for knowledge, is related to how the auditor process the evidence. Based on this, this study argue that suspension of judgment becomes an important supplementary trait that the auditors had to make decisions carefully. The auditor will not perform the judgment before he/she satisfied with the evidence. With better commitment, he/she has and supports by skepticism behavior; it will decrease the intention to sign-off prematurely. The discussion leads to the hypothesis:

$\mathrm{H}_{3}$ : Suspension of judgment mediated the relationship between professional commitment and premature sign-off.

\section{RESEARCH METHOD}

\section{Sampling}

The population in this research is auditors who are working at big ten public accounting firms in Indonesia. Before distributing the questionnaire, a pilot test was conducted to 15 participants to obtain feedback in improving the quality of the questionnaire. The questionnaires were distributed using a web-based survey to reach more respondents. All the procedure follows Dillman (2000). Approximately 310 questionnaires were distributed to Auditors who work in the Big-Ten Public Accounting firms in Indonesia. One hundred twenty-six questionnaires were correctly filled completed, resulting in a response rate of $40.64 \%$ for this research. Most of the respondents are male auditors as many as 100 people, with $79.37 \%$. Meanwhile, female auditors participating in this research are only 26, with a percentage of $20.63 \%$. The respondents of this research are mostly the auditors aged between $21-25$ years old as many as 79 people with a rate of $62.70 \%$.

Of $100 \%$ respondents, $2.38 \%$ auditors had working experience more than 17 years, $4.76 \%$ had eleven to sixteen years working experience, $15.08 \%$ had five to ten years working experience, and $77.78 \%$ had less than five years working experience. Therefore, this research dominated by an auditor as associate auditor and supervisor (42.86\% and $23.81 \%$ ), which indicated that all respondents are sufficiently experienced as an auditor. Followed by $18.25 \%$ worked as a junior auditor, $12.70 \%$ worked as a manager, $1.59 \%$ worked as a partner, and $0.79 \%$ worked as directors.

\section{Measurement}

\section{Professional Commitment}

Professional commitment defined as the auditor's dedication and responsibility to execute the auditing standards while performing their job. This variable was measured using scales developed by Klein et al. (2014). The range has consisted of items using a Likert scale of 1 to 5 points. One example of this instrument's statements is, "How dedicated are you to the profession?". 


\section{Suspension of Judgement}

Suspension of judgment defined as the auditor's intention to hold their opinion until they found sufficient evidence. This variable was measured using scales developed by Hurtt (2010). Hurtt (2010) developed the scale to measure the professional skepticism in which suspension of judgment is one of the characteristics of skeptics. Items used in measuring suspension of judgment using a Likert scale that consist of 1 to 5 points. The sample statement is, "I often reject statements unless I have proof that they are true."

\section{Premature Sign-off}

Premature sign-off evaluated the auditor's response on how they finish the job if several audit procedures were skipped or omitted. This variable was measured using items questions developed by Raghunatan (1991). This variable was measured using a Likert scale that consists of 1 to 5 points. The sample statement of these items is, "How frequent you publish financial information without doing an analytical review?".

\section{Statistical Analysis}

Structural Equation Modelling (SEM) is used for this research to analyze the data. According to Hair et al. (2013), using an SEM-PLS tool in analyzing is quite significant. Thus, the sample used in this research could be categorized as a small sample using SEM-PLS is effective since SEM-PLS can handle complex construct and even a small sample size. Additionally, according to Chin and Newsted (1999), using the PLS approach in this study, the structural model could maximize the variance described by variables in this study model with R-square as the goodness-of-fit measure.

\section{RESULT}

\section{Measurement Model Analysis}

The relationship between the indicators (measures) with the construct that they represent could be examined through the measurement model. Through the measurement model, the researcher can identify the validity and reliability of indicators related to specific constructs. Besides, the structural model assesses the relationships between constructs. Although the structural and measurement models can be evaluated together, they should be interpreted independently (Hulland, 1999).

\section{Validity and Reliability Test}

The evaluation of validity in this research tested by the convergent and discriminant test. In testing convergent validity, this study used Average Variance Extracted (AVE). According to Hulland (1999), a construct should have an AVE measure of 0.50 or more so that it could be considered as having adequate convergent validity. As stated by Hair et al. (2013) and Chin (1998a, 1998b) that if each indicator has a loading value of more than 0.70 and a significant p-value less than 0.05 , the validity of convergent can be supported.

All the data presented in Table 1 are the data with AVE more than 0.50, and the AVE in Table 1, ranging from the smallest, which is 0.516 to the highest 0.782 , means that it becomes evidence of adequate convergent validity. Additionally, to test the indicators' reliability, the value of Cronbach Alpha and composite reliability should be more than. 0.7 (Chin and Newsted, 1999). The composite reliabilities of this study are above the minimum level, with the minimum score is 0.838 to 0.935 . The researcher decided that all the data has been qualified with their validity and reliability test. 
Table 1. Reliability and Convergent Validity

\begin{tabular}{|c|c|c|c|}
\hline & Mean & SD & Loading \\
\hline \multicolumn{4}{|l|}{ Professional Commitment $($ Composite Reliability $=0.935 ; \mathrm{AVE}=0.782)$} \\
\hline I do care about the audit profession & 4.28 & 0.81 & 0.768 \\
\hline How dedicated are you to the audit profession? & 4.15 & 0.82 & 0.909 \\
\hline $\begin{array}{l}\text { To what extent have you chosen to be committed to the audit } \\
\text { profession? }\end{array}$ & 4.10 & 0.85 & 0.915 \\
\hline How committed are you to the audit profession? & 4.09 & 0.89 & 0.935 \\
\hline \multicolumn{4}{|l|}{ Suspension of Judgement (Composite Reliability $=0.838 ; \mathrm{AVE}=0.569)$} \\
\hline $\begin{array}{l}\text { I like to ensure that I have considered the most available } \\
\text { information before making a decision }\end{array}$ & 4.33 & 0.84 & 0.762 \\
\hline I often reject statements unless I have proof that they are true & 3.95 & 0.83 & 0.583 \\
\hline I wait to decide on issues until I can get more information & 4.22 & 0.64 & 0.836 \\
\hline $\begin{array}{l}\text { I do not like to decide until I have looked at all of the readily } \\
\text { available information }\end{array}$ & 4.10 & 0.89 & 0.809 \\
\hline \multicolumn{4}{|l|}{ Premature Sign-off $($ Composite Reliability = 0.840; AVE = 0.516) } \\
\hline $\begin{array}{l}\text { I often publish financial information without verifying the } \\
\text { information contained in a footnote disclosure }\end{array}$ & 1.48 & 0.66 & 0.653 \\
\hline $\begin{array}{l}\text { I often publish financial information without testing work } \\
\text { performed by the client's internal auditors }\end{array}$ & 1.74 & 0.94 & 0.705 \\
\hline $\begin{array}{l}\text { I often publish financial information without testing how well the } \\
\text { client's internal controls work in practice }\end{array}$ & 1.63 & 0.89 & 0.604 \\
\hline $\begin{array}{l}\text { I often publish financial information without doing a substantive } \\
\text { test }\end{array}$ & 1.48 & 0.80 & 0.805 \\
\hline $\begin{array}{l}\text { I often publish financial information without obtaining } \\
\text { representation from management and outside legal counsel }\end{array}$ & 1.70 & 1.01 & 0.803 \\
\hline
\end{tabular}

When the square roots of AVE of its construct have to value that higher than to the other construct, the data can be considered as valid data. Fornell and Larcker (1981) stated that the research found has discriminant validity if the square root of AVE has a higher value than correlation among variables and located in the same column. Table 2 presents the comparison evidence of the square roots of AVE. As shown in table 2, all the diagonal elements have a higher value than the correlation between each variable. The researcher concludes that the discriminant validity of this study was accepted.

Table 2. Discriminant Validity

\begin{tabular}{llll}
\hline & PC & SOJ & PSO \\
\hline Professional Commitment & $(0.884)$ & & \\
Suspension of Judgement & 0.423 & $(0.754)$ & \\
Premature Sign-off & -0.236 & -0.482 & $(0.718)$ \\
\hline
\end{tabular}

Diagonal element: square root of AVE; off-diagonal: correlation between constructs

After determined the validity of the data, this study identified the reliability of the constructs. According to Fornell and Larcker (1981), to see if the constructs are reliable, the Cronbach's alpha should be equal or higher than 0.70 , and an even more relaxed version sets this threshold at 0.6 (Nunnally and Bernstein, 1994). As stated in Table 3, the Cronbach's alpha for each variable has valued at least 0.744 . The researcher's sum that composite reliability is excellent.

Table 3. Reliability

\begin{tabular}{lccc}
\hline & PC & SOJ & PSO \\
\hline Cronbach Alpha & 0.905 & 0.744 & 0.771 \\
\hline
\end{tabular}


THE ROLE OF PROFESSIONAL COMMITMENT AND SUSPENSION OF JUDGMENT IN DECREASING AUDITORS' PREMATURE SIGN-OFF

Andi Ina Yustina dan Irina Kristela Sutarsa

\section{Structural Model Analysis}

In testing the hypothesis, this research used structural model analysis, particularly to examine whether the suspension of judgment on premature sign-off is direct, and also professional commitment is indirect as the suspension of judgment mediates it. Table 4 and figure 1 presented the result of hypothesis testing. This research used an approach named stepwise in performing analysis of our structural model (Baron and Kenny, 1986). The results show that professional commitment positively related to the suspension of judgment (path coefficient: $0.423: \mathrm{p}<0.01)$. Therefore, hypothesis $\mathrm{H}_{1}$, which states that professional commitment has a positive relation towards the suspension of judgment, is supported.

We also did the same procedure to test $\mathrm{H}_{2}$, which results in that suspension of judgment is negatively related to premature sign-off (path coefficient:-0.465;p>0.01). Therefore, hypothesis $\mathrm{H}_{2}$, which states that suspension of judgment has a negative relation towards premature sign-off, is supported.

Table 4. Structural Model Result

\begin{tabular}{lcccc}
\hline & $\begin{array}{c}\text { Path } \\
\text { Coefficient }\end{array}$ & T-value & p-value & Result \\
\hline PC -> SOJ (Hypothesis 1) & 0.423 & 4.515 & 0.000 & Supported \\
SOJ -> PSO (Hypothesis 2) & -0.465 & 5.712 & 0.000 & Supported \\
PC -> SOJ -> PSO (Hypothesis 3) & -0.197 & 3.254 & 0.001 & Supported \\
\hline
\end{tabular}

Next, we can also see that suspension of judgment mediating the relation between professional commitment towards premature sign-off. In testing the mediating role, this study using the Variance Accounted For (VAF) method developed by Preacher and Hayes (2004; 2008), as suggested by Hair et al. (2013). According to Hair et al. (2013), this test is more powerful than Sobel's test. If the VAF value is above $80 \%$, then the variable is fully mediated, range between $20 \%-80 \%$, then it is partially mediated, then below $20 \%$, the variable is not mediated. Based on table 5, VAF value for the mediating role of SOJ is $0.831(83.1 \%)$, then it can be concluded that the variable is fully mediated. As the statement above, hypothesis $\mathrm{H}_{3}$, which states that suspension of judgment mediated the negative relationship of professional commitment towards premature sign-off, is supported.

Table 5. VAF Test

\begin{tabular}{lcc}
\hline Indirect effect (PC-SOJ-PSO) & -0.197 \\
Direct effect (PC-PSO) & & -0.040 \\
Total effect & & -0.237 \\
\hline VAF & $-0.197 /-0.237$ & 0.831 \\
\hline
\end{tabular}

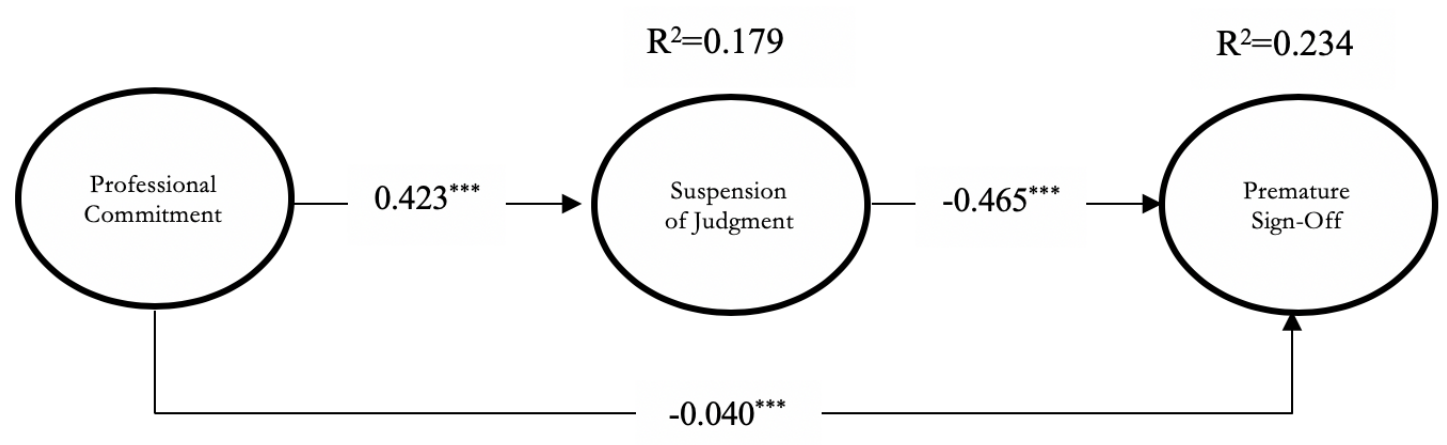

Figure 1. Full Model 


\section{Discussion and Implications}

This study proposed that suspension of judgment could be the mediating variable between professional commitment and premature sign-off. This study also examined the mixed result of the previous research on the relationship between professional commitment towards premature sign-off. The result shows that both professional commitment and suspension of judgment could decrease an auditor's intention to do a premature sign-off. The supported result of this study could give more awareness for public accountants and accounting firms to minimize the number of premature sign-off occurred to increase and maintain the quality of audit outcomes. Applied theory from Nelson (2009) state that when auditors with a more skeptical disposition will exhibit more skeptical judgments and decisions than auditors with a less suspicious placement.

The hypothesis from professional commitment is reflected in a high level of professional commitment; the auditors are likely not performing premature sign-off. This result is confirmed to the study conducted by Kaplan and Whitecotton (2001), where there is a positive relationship between effective professional commitment and auditor's responsibility for reporting, which supported by the result that the auditor is less likely to perform premature sign-off. Thus, they tend to be more concern about their future careers as professional auditors. A high level of professional commitment also showed that the auditors have a great responsibility to comply with the audit professional standards.

Lastly, the suspension judgment hypothesis as the mediating role in the relationship between professional commitment and premature sign-off is fully mediating. The fully mediating means that professional auditors with a high level of suspension of judgment after in line with a high level of professional commitment will decrease the intention of auditors to do premature sign-off. However, there are still other factors that also can influence professional commitment to reducing the tendency to do premature sign-off.

\section{CONCLUSION}

This study introduces the impact of professional commitment and suspension of judgment in minimizing the intention of auditors to do premature sign-off. One hundred twenty-six collected data from professional auditors Big-Ten public accounting in Indonesia using a web-based survey. The researcher using SEM PLS as the statistical analysis tool to test the three hypotheses.

The result shows that professional commitment positively related to the suspension of judgment. Furthermore, professional commitment could minimize the auditor's intention to do premature sign-off. This study also proved that suspension of judgment is effectively meditating the relationship between professional commitment and premature sign-off. This result demonstrates that auditors' high level of professional traits is essential to minimize the intention to do dysfunctional behavior. Thus, public accounting firms and the auditors themselves must enhance the professional characteristics that will be resulted in good quality of the outcome.

The limitations of this study come from the method of collecting the data. This study only used a web-based survey method with several weaknesses, such as several questionnaires that did not answer and could result in a low response rate. The next research could use another way, for instance, interview. Due to the limitations of time, the researcher could only gather data among public accountants in Jakarta. Future research could expand to broader areas.

The last, this research only uses one characteristic among the six attributes of the professional skepticism model developed by Hurtt (2010). Future research could individually 
examine another component, for instance, questioning mind and search for knowledge to explore the impact on the intention of premature sign-off. Other variables, for example, audit tenure, audit experience, or audit rotation, could be used in examining to detect the relationship between professional commitment and premature sign-off (Herda and Martin, 2016).

\section{REFERENCES}

Ajzen, I. (2005). Attitudes, Personality, and Behavior. Berkshire: Open University Press.

Alderman, C. and Deitrick, J. (1982), Auditors' Perceptions of Time Budget Pressures and Premature Sign-Offs: A Replication and Extension. Auditing: A Journal of Practice \& Theory, 1, 54-68.

Aranya, N., and Ferris, K.R. (1984). A Reexamination of Accountants' Organizational, Professional Conflict. The Accounting Review, 59(1), 1-15.

Baron, R. M., \& Kenny, D. A. (1986). The Moderator-Mediator Variable Distinction in Social Psychological Research: Conceptual, Strategic, and Statistical Considerations. Journal of Personality and Social Psychology, 51, 1173-1182.

Becker, H.S. (1960). Notes on the Concept of Commitment. American Journal of Sociology, $66,32-42$.

Chiang, C. (2016). Conceptualizing the Link Age Between Professional Skepticism and Auditor Independence. Pacific Accounting Review. 28(2), 180-200.

Chin, W. W. (1998a). Issues and Opinion on SEM. MIS Quarterly, 22(1), 7-16.

Chin, W. W. (1998b). The Partial Least Squares Approach to Structural Equation Modeling. In G. A. Marcoulides (Ed.), Modern Methods for Business Research. London: Lawrence Erlbaum Associates.

Chin, W. W., and Newsted, P. R. (1999). Structural Equation Modeling Analysis with Small Samples Using Partial Least Squares. In R. H. Hoyle (Ed.), Statistical strategies for small sample research. Thousand Oak: Sage Publication.

Consideration of Fraud in a Financial Statement Audit. (1997a). Statement on Auditing Standards. 82.

Dillman, D. A. (2000). Mail and Internet Survey: The Tailored Design Method. 2nd edition. New York, NY: John Wiley and Sons.

Due Care in the Performance of Work. (1997b). Statement on Auditing Standards. 1.

Fornell, C., and Larcker, D. F. (1981). Erratum: Structural Equation Models with Unobservable Variables and Measurement Error: Algebra and Statistics. Journal of Marketing Research, 18(3), 328-388.

Grey, C. (1998). On Being a Professional in a Big Six Firm. Accounting, Organizations, and Society. 23(5), 569-587.

Hair, J. F., Hult, G. T., Ringle, C., and Sarstedt, M. (2013). A Primer on Partial Least Squares Structural Equation Modeling (PLS-SEM). SAGE Publications.

Hall, M., D. Smith, and K. Langfield-Smith. (2005). Accountants' Commitment to Their Profession: Multiple Dimensions of Professional Commitment and Opportunities for Future Research. Behavioral Research in Accounting, 17, 89-109.

Hallie, P. (1985). Skepticism, Narrative, and Holocaust Ethics. The Philosophical Forum, 16(1), 33-49.

Herda, D.N., and Martin, K.A. (2016). The Effects of Auditor Experience and Professional Commitment on Acceptance of Underreporting Time: A Moderated Mediation Analysis. Current Issues in Auditing, 10(2), 14-27.

Hulland, J. (1999). Use of Partial Least Squares (PLS) in Strategic Management Research: A 
Review of Four Recent Studies. Strategic Management Journal. 20(2), 195-204.

Hurtt, R.K. (2010). Development of A Scale to Measure Professional Skepticism. Auditing: A Journal of Practice \& Theory. 29(1), 149-171.

Hurtt, R. K., Brown-Liburd, H., Earley, C. E., and Khrisnamoorty, G. (2013). Research on Auditor Professional Skepticism: Literature Synthesis and Opportunities for Future Research. Auditing: A Journal of Practice and Theory. 32(1), 45-97.

Kaplan, S., and Whitecotton, S. (2001). An Examination of Auditors' Reporting Intentions When Another Auditor Is Offered Client Employment. Auditing: A Journal of Practice \& Theory. 20(1), 44-63.

Kelley, T., and Margheim. L. (1990). The Impact of Time Budget Pressure, Personality, and Leadership Variables on Dysfunctional Auditor Behavior. Auditing: A Journal of Practice \& Theory. 9, 21-42.

Klein, H.J., Cooper, J.T., Molloy, J.C., and Swanson, J.A. (2014). The Assessment of Commitment: Advantages of A Unidimensional, Target-Free Approach. Journal of Applied Psychology. 99(2), 222-238.

Kruglanski, A. W. (1989). Lay Epistemic and Human Knowledge: Cognitive and Motivational Biases. New York, NY: Plenum Press.

Kurtz, P. (1992). The New Skepticism: Inquiry and Reliable Knowledge. Buffalo, NY: Prometheus Books.

Lee, B. (2002). Professional Socialization, Commercial Pressures and Junior Staff's TimePressures Irregular Auditing: A Contextual Interpretation. British Accounting Review. 34(4), 315-333.

Ling, Q. and Akers, M. (2010). An Examination of Underreporting of Time and Premature Sign-Off by Internal Auditors. Review of Business Information Systems. 14(4), 37-48.

Lord, A. T and DeZoort, F.T. (2001). The Impact of Commitment and Moral Reasoning on Auditors' Responses to Social Influence Pressure. Accounting, Organization, and Society. 26, 215-235.

Meyer, J.P., Allen, N.J., and Smith, C.A. (1993). Commitment to Organization and Occupations: Extensions and Test of a Three-Component Conceptualization. Journal of Applied Psychology. 78(4), 538-551.

Meyer, J.P., and Allen, N.J. (1997) Commitment in the Workplace: Theory, Research, and Application. Thousand Oaks. CA: Sage.

Nelson, M.W. (2009). A Model and Literature Review of Professional Skepticism in Auditing. Auditing: A Journal of Practice \& Theory. 28(2), 1-34.

Obeid, M., Salleh, Z., Nor. M. N. M. (2017). The Mediating Effect of Job Satisfaction on The Relationship Between Personality Traits and Premature Sign-Off. Academy of Accounting and Finance Studies Journal. 21(2), 1-17.

Otley, D. T., and Pierce, B. J. (1996). The operation of control systems in large auditing Firms. Auditing: A Journal of Theory and Practice. 15(2), 65-84.

Otley, D., and Pierce. B. (1995). The Control Problem in Public Accounting Firms: An Empirical Study of The Impact of Leadership Style. Accounting, Organizations, and Society. 20, 405-420.

Paino, H., Ismail, Z., and Smith, M. (2010). Dysfunctional Audit Behavior: An Exploratory Study in Malaysia. Asian Review of Accounting. 18(2), 162-173.

Raghunatan, B. (1991). Premature Signing-Off of Audit Procedures: An Analysis. Accounting Horizons. 18(3), 78-90.

Rhode, J. (1977). Summarized in the Commission on Auditor's Responsibilities: Report of Tentative Conclusions. Survey on the Influence of Selected Aspects of the Auditor's Work Environment on Professional Performance of Certified Public Accountants, The Commission on Auditor's Responsibility, New York, NY. 
THE ROLE OF PROFESSIONAL COMMITMENT AND SUSPENSION OF JUDGMENT IN DECREASING AUDITORS' PREMATURE SIGN-OFF

Andi Ina Yustina dan Irina Kristela Sutarsa

Shapeero, M., Koh, H.C., and Killough, L.N. (2003). Underreporting and Premature Sign Off in Public Accounting. Managerial Auditing Journal. 8(6), 478-489.

Svanberg. J., and Öhman. (2019). Auditors' Issue Contingency of Reduced Audit Quality Act: Perceptions of Managers and Partners. International Journal Accounting, Auditing and Performance Evaluation. 15(1), 57-87.

Yustina, A. I., and Gonadi, S. A. (2019). The Negative Effect of Time Budget Pressure to Auditor Independence and Professional Skepticism. Jurnal Akuntansi dan Keuangan. 21(1), 38-48. 